\title{
Perceptions of Fathers and Special Education Teachers Concerning Oral Health of Children with Down Syndrome: A Qualitative Approach
}

FARIS ALGAHTANI ( $\sim$ fhalqahtani@uj.edu.sa )

Keywords:

Posted Date: May 6th, 2020

DOl: https://doi.org/10.21203/rs.3.rs-25372/v1

License: (c) (i) This work is licensed under a Creative Commons Attribution 4.0 International License.

Read Full License 


\section{Abstract}

The authors have requested that this preprint be removed from Research Square. 